\title{
A SURVEY OF RHEUMATISM IN A RURAL NEW ZEALAND MAORI COMMUNITY
}

BY

\author{
B. S. ROSE AND I. A. M. PRIOR \\ From the Queen Elizabeth Hospital for Rheumatic Diseases, Rotorua, \\ and the Medical Unit, Wellington Hospital, New Zealand
}

Previous surveys of the coastal rural Whanau-aApanui (Rose, 1956) and of the urban Arawa Maori of Rotorua (Lennane, Rose, and Isdale, 1960) have shown a high prevalence of gout and a low prevalence of rheumatoid arthritis (Rose and Isdale, 1961). In these earlier surveys no attempt was made fully to determine the distribution of positive rheumatoid serum agglutination tests, serum uric acid levels, or $x$-ray changes in the population samples studied.

This present survey was designed as a further check on the previous findings and as a remedy for these previous deficiencies. It is part of a wider health survey of the rural inland Tuhoe Maori (Prior, 1962), with particular emphasis on cardiovascular, nutritional, and metabolic data.

\section{Methods}

458 of the total 491 inhabitants of Ruatahuna were interviewed and examined, only four of the adults residing in the valley refusing to participate. Of the remaining 29 absent residents, only six were over 20 years old. This gave a completion rate of 99 per cent. of those available and of $93 \cdot 3$ per cent. of the total population. The distribution of the 212 "adults" of 15 years and upwards is shown in Table $I$.

These adults were questioned about the presence of morning stiffness and pain or swelling in their joints at any time in the previous 5 years. Joints were examined, hands $x$ rayed, and blood taken for latex-agglutination tests and serum uric acid and serum cholesterol estimations. Serum was deep frozen during the period of the survey and aliquots were subsequently examined for cholesterol at the Wellington Hospital Medical Unit by the method of Abell (1960), and for uric acid content and
TABLE I

RUATAHUNA ADULT POPULATION STUDIED SAMPLE SIZES ON WHICH DATA IS BASED, BY AGE AND SEX

\begin{tabular}{c|c|c}
\hline \multirow{2}{*}{ Age Group (yrs) } & \multicolumn{2}{|c}{ Sex } \\
\cline { 2 - 3 } & Male & Female \\
\hline $15-19$ & 18 & 19 \\
\hline $20-29$ & 33 & 24 \\
\hline $30-39$ & 15 & 23 \\
\hline $40-49$ & 23 & 16 \\
\hline $50-59$ & 7 & 8 \\
\hline $60-69$ & 11 \\
\hline $70+$ & 3 & 8 \\
\hline Total.. &.. & 4 \\
\hline
\end{tabular}

latex-agglutination at Rotorua. Sera were kept deep frozen when not being tested, adequate time being allowed for fall off in non-uric acid chromogen content. Serum uric acid was estimated by the non-enzymatic spectrophotometric method of Beale (1954), which in our hands yields consistent results similar to those recorded by Hendry, White, and Stanger (1959). The upper limit of normal for clinical purposes when the method has been used in New Zealand Europeans is $6 \mathrm{mg} . / 100 \mathrm{ml}$. for women and $7 \mathrm{mg} . / 100 \mathrm{ml}$. for men. The standard error of the method using pooled sera replicates is $\pm 0.28 \mathrm{mg} . / 100 \mathrm{ml}$.

Latex-agglutination tests were carried out by the "Hyland" technique of Rheins, McCoy, Burrell, and Buehler (1957), titres of 1:40 and over being accepted as positive. 
$X$ rays of the hands only were taken by mass miniature radiography, which was being used in the field at the same time for the cardiovascular survey. This method requires considerable experience in interpretation. When checked against standard films in hospital patients it is found to record satisfactorily all but the most doubtful osteophytes and erosions, but observers with insufficient experience tend to overreport osteoporosis or diminution of joint spaces in the wrist.

\section{Results}

The rheumatoid arthritis gradient, expressed as the proportion of individuals fulfilling a given number of the criteria of the American Medical Association (Kellgren, 1962), is shown in Table II.

Amongst those with these positive criteria, seven (3.3 per cent.) fulfilled the requirements for a diagnosis of probable or definite rheumatoid arthritis. The distribution of rheumatic disorders by diagnosis is detailed in Table III.

The group with "arthralgia" (not otherwise designated) would have included one male and four females with "possible" rheumatoid arthritis under the old American Rheumatism Association criteria.

Positive latex-agglutination tests were obtained in eight men ( $7 \cdot 3$ per cent. of males) and three women ( 2.9 per cent. of females), that is $5 \cdot 2$ per cent. of all those examined. The particulars of these eleven cases are given in Table IV.

Thus all the women with positive agglutination tests also had rheumatic symptoms, but none of the three women having "definite" or "probable"
TABLE IV

ELEVEN PERSONS WITH POSITIVE LATEXAGGLUTINATION TEST

\begin{tabular}{|c|c|c|c|c|}
\hline Sex & $\begin{array}{l}\text { Case } \\
\text { No. }\end{array}$ & $\begin{array}{l}\text { Age } \\
\text { (yrs) }\end{array}$ & $\begin{array}{c}\text { Dilu- } \\
\text { tion }\end{array}$ & Remarks \\
\hline \multirow{4}{*}{ Male } & $\begin{array}{r}63 \\
4 \\
18\end{array}$ & $\begin{array}{l}24 \\
49 \\
54\end{array}$ & $\begin{array}{l}1: 40 \\
1: 320 \\
1: 40\end{array}$ & $\begin{array}{l}\text { Painful knee after old injury. } \\
\text { "Classical" rheumatoid arthritis. } \\
\text { Painful joints with changes in } \\
\text { weather; squaring of lower radius } \\
\text { on } x \text { ray. }\end{array}$ \\
\hline & 162 & 62 & $\begin{array}{l}1: 80 \\
1: 80\end{array}$ & $\begin{array}{l}\text { Degenerative joint disease on hand } \\
x \text { ray; hyperuricaemia } 9.4 \mathrm{mg} . / \\
100 \mathrm{ml} . ; \text {; aching in hand and arm. } \\
\text { "Probable" rheumatoid arthritis; } \\
\text { mechanical derangement of knee } \\
\text { joint. }\end{array}$ \\
\hline & $\begin{array}{r}61 \\
120\end{array}$ & $\begin{array}{l}62 \\
65\end{array}$ & $\begin{array}{l:l}1: 640 \\
1: 320\end{array}$ & $\begin{array}{l}\text { Recurrent multiple joint pains. } \\
\text { Hyperuricaemia } 8 \cdot 5 \mathrm{mg} . / 100 \mathrm{ml} \text {; } \\
\text { painful knees and shoulders. }\end{array}$ \\
\hline & 71 & 85 & $1: 40$ & $\begin{array}{l}\text { "Probable" rheumatoid arthritis; } \\
\text { degenerative joint disease on } \\
\text { hand } x \text { ray. }\end{array}$ \\
\hline \multirow{3}{*}{ Female } & 16 & 48 & $1: 40$ & Morning stiffness; joint swelling; \\
\hline & 98 & 65 & $1: 40$ & Joint pain and tenderness; recurrent \\
\hline & 102 & 61 & $1: 40$ & $\begin{array}{l}\text { Painful hands and knees; degenera- } \\
\text { tive joint disease on hand } x \text { ray; } \\
\text { hyperuricaemia } 8 \cdot 3 \mathrm{mg} . / 100 \mathrm{ml} \text {. }\end{array}$ \\
\hline
\end{tabular}

rheumatoid arthritis was sero-positive. The presence of rheumatoid arthritis (classical, definite, and probable) in seven of 212 Tuhoe Maori in the present study (3.3 per cent.) was similar to that in six of 186 Arawa Maori of Rotorua (3.2 per cent.) recorded by Rose and Isdale (1961), and correspondingly less than recorded by them in 78 of the 641 Europeans in Rotorua (12.5 per cent.).

TABLE II

DISTRIBUTION OF CRITERIA* OF RHEUMATOID ARTHRITIS, BY SEX

\begin{tabular}{|c|c|c|c|c|c|c|c|c|}
\hline Sex & $\begin{array}{l}\text { Morning } \\
\text { Stiffness }\end{array}$ & $\begin{array}{l}\text { Joint Pain or } \\
\text { Tenderness }\end{array}$ & $\begin{array}{c}\text { Joint } \\
\text { Swelling }\end{array}$ & $\begin{array}{l}\text { Swelling in } \\
\text { More than } \\
\text { One Joint }\end{array}$ & $\begin{array}{l}\text { Symmetry of } \\
\text { Joint Swelling }\end{array}$ & $\begin{array}{c}\text { Subcutaneous } \\
\text { Nodules }\end{array}$ & $\begin{array}{c}X \text {-ray } \\
\text { Changes }\end{array}$ & $\begin{array}{c}\text { Positive Latex- } \\
\text { Agglutination } \\
\text { Test } \\
\text { (see Table IV) }\end{array}$ \\
\hline Male $\ldots$ & 18 & 11 & 11 & 5 & 4 & 1 & 1 & 8 \\
\hline Female .. & 16 & 8 & 6 & 4 & 2 & 1 & 0 & 3 \\
\hline
\end{tabular}

* American Rheumatism Association

TABLE III

DISTRIBUTION OF RHEUMATIC DISORDERS AMONG 212 ADULTS (110 MALE, 102 FEMALE), BY SEX

\begin{tabular}{|c|c|c|c|c|c|c|c|c|c|c|c|c|c|}
\hline \multirow[b]{2}{*}{$\operatorname{Sex}$} & \multicolumn{3}{|c|}{ Rheumatoid Arthritis } & \multirow{2}{*}{$\begin{array}{l}\text { Anky- } \\
\text { losing } \\
\text { Spon- } \\
\text { dylitis }\end{array}$} & \multicolumn{2}{|c|}{ Gout } & \multirow{2}{*}{$\begin{array}{l}\text { Osteo- } \\
\text { Arth- } \\
\text { ritis }\end{array}$} & \multirow{2}{*}{$\begin{array}{c}\text { Arthralgia } \\
\text { (not } \\
\text { otherwise } \\
\text { designated) }\end{array}$} & \multirow{2}{*}{$\begin{array}{l}\text { Neuro- } \\
\text { arthro- } \\
\text { pathy }\end{array}$} & \multirow{2}{*}{$\begin{array}{l}\text { Tuber- } \\
\text { cular } \\
\text { Joint }\end{array}$} & \multirow{2}{*}{$\begin{array}{l}\text { Rheu- } \\
\text { matic } \\
\text { Fever }\end{array}$} & \multirow{2}{*}{$\begin{array}{c}\text { Non- } \\
\text { articular } \\
\text { Rheu- } \\
\text { matism }\end{array}$} & \multirow{2}{*}{ Total } \\
\hline & $\begin{array}{c}\text { Classi- } \\
\text { cal }\end{array}$ & $\underset{\text { nite }}{\text { Defi- }}$ & $\begin{array}{c}\text { Prob- } \\
\text { able }\end{array}$ & & $\begin{array}{c}\text { Defi- } \\
\text { nite }\end{array}$ & $\begin{array}{c}\text { Prob- } \\
\text { able }\end{array}$ & & & & & & & \\
\hline Male & 1 & 1 & 2 & 0 & 5 & 1 & 7 & 25 & 1 & 1 & 0 & 5 & 49 \\
\hline Female & 0 & 2 & 1 & 0 & 2 & 0 & 6 & 30 & 0 & 0 & 1 & 6 & 48 \\
\hline
\end{tabular}


There was $x$-ray evidence of degenerative joint disease in the hands of fifteen males and eight females (Table V). Erosions were not seen, but the one man with "classical" rheumatoid arthritis had osteoporosis of the wrist.

TABLE $\mathbf{V}$

DISTRIBUTION OF DEGENERATIVE JOINT DISEASE OF THE HAND AMONG 212 ADULTS (110 MALE, 102 FEMALE), BY AGE AND SEX

\begin{tabular}{c|c|c|c|c|c|c|c|c}
\hline \multirow{2}{*}{ Sex } & \multicolumn{5}{c|}{ Age Group (yrs) } & \\
\cline { 2 - 6 } & $15-19$ & $20-29$ & $30-39$ & $40-49$ & $50-59$ & $60-69$ & $70+$ & Total \\
\hline Male .. & - & 1 & 1 & 5 & 4 & 2 & 2 & 15 \\
\hline Female .. & - & - & 1 & - & 2 & 3 & 2 & 8 \\
\hline
\end{tabular}

One subject had rheumatoid arthritis changes (osteoporosis of the wrist). See Table II

\section{Gout and Serum Uric Acid Data}

The serum uric acid distributions for 109 males and 99 females are shown in Table VI with the mean level in each age group and the standard deviation. The percentages above 6 and $7 \mathrm{mg}$. $/ 100 \mathrm{ml}$. are shown for males and females respectively.

The frequency distribution levels for serum uric acid in the two sexes are shown in the Figure (opposite).

Five of 110 males ( 4.5 per cent.) had definite gout by combined clinical and biochemical criteria; and one other was almost certainly gouty, but had diabetes and a serum uric acid level of only 6.9 $\mathrm{mg} . / 100 \mathrm{ml}$. at the time of the survey. If he had not had to be thus arbitrarily excluded, a gout prevalence of 5.5 per cent. would have been found amongst the adult males. All had a classical podagra history and two were diabetic. The

TABLE VI

SERUM URIC ACID (mg./100 ml.) IN 109 MALES AND 99 FEMALES, BY AGE GROUP

\begin{tabular}{|c|c|c|c|c|c|c|c|c|c|c|c|c|c|c|c|c|c|c|c|c|c|c|c|c|c|}
\hline Sex & $\underset{\substack{\text { Age } \\
\text { (yrs) }}}{ }$ & $\begin{array}{c}\text { No. } \\
\text { of } \\
\text { Cases }\end{array}$ & 2 & $2 \cdot 5$ & 3 & $3 \cdot 5$ & 4 & $4 \cdot 5$ & 5 & $5 \cdot 5$ & 6 & $6 \cdot 5$ & 7 & $7 \cdot 5$ & 8 & $8 \cdot 5$ & 9 & $9 \cdot 5$ & 10 & $10 \cdot 5$ & 11 & $11 \cdot 5$ & Mean & S.D. & $\begin{array}{l}\text { Percentage Over } \\
7 \text { per cent. for } \\
\text { Males and } 6 \text { per- } \\
\text { cent. for Female }\end{array}$ \\
\hline & $15-19$ & 18 & & & & & & 1 & 3 & 1 & 3 & 1 & 2 & 3 & 2 & 1 & & & 1 & & & & $7 \cdot 01$ & 1.44 & 50 \\
\hline & $20-29$ & 32 & & & & & & 1 & & 3 & 8 & 3 & 4 & 7 & 4 & & 2 & & & & & & $7 \cdot 17$ & $1 \cdot 03$ & 53 \\
\hline \multirow{7}{*}{ Male } & $30-39$ & 15 & & & & & & & 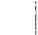 & 1 & 2 & 2 & 4 & 3 & 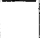 & 2 & 1 & & & & & & $7 \cdot 44$ & 0.99 & 66 \\
\hline & $40-49$ & 23 & & & & & & & 1 & 2 & 2 & 3 & 2 & 1 & 4 & 3 & 1 & 2 & 1 & 1 & & & $7 \cdot 94$ & $1 \cdot 52$ & 65 \\
\hline & $\begin{array}{l}\text { Total } \\
15-49\end{array}$ & 88 & & & & & & 2 & 4 & 7 & 15 & 9 & 12 & 14 & 10 & 6 & 4 & 2 & 2 & 1 & & & & & 58 \\
\hline & $50-59$ & 7 & & & & & & & & & 1 & & 2 & 1 & & 2 & 1 & & & & & & $7 \cdot 52$ & $1 \cdot 11$ & 85 \\
\hline & $60-69$ & 11 & & & & & & & 1 & 1 & & 3 & & 2 & 2 & 1 & & 1 & & & & & $7 \cdot 32$ & $1 \cdot 27$ & 54 \\
\hline & $\begin{array}{l}70 \text { and } \\
\text { Over }\end{array}$ & 3 & & & & & & & 1 & & 1 & & & 1 & & & & & & & & & $6 \cdot 6$ & $1 \cdot 21$ & 33 \\
\hline & $\begin{array}{c}\text { Total } \\
50-70+\end{array}$ & 21 & & & & & & & 2 & 1 & 2 & 3 & 2 & 4 & 2 & 3 & 1 & 1 & & & & & & & 62 \\
\hline \multirow{9}{*}{ Female } & $15-19$ & 18 & 1 & & & & 2 & 1 & 3 & 5 & 1 & 3 & 2 & & & . & & & & & & & $5 \cdot 71$ & $1 \cdot 14$ & 33 \\
\hline & $20-29$ & 23 & & & & 2 & 2 & 4 & 4 & 2 & 1 & 2 & 2 & 1 & & 2 & & & & 1 & & & 6.03 & $1 \cdot 8$ & 39 \\
\hline & $30-39$ & 23 & & & & 1 & & 4 & 5 & 2 & 3 & 2 & 2 & 1 & & & 1 & 2 & & & & & $6 \cdot 32$ & $1 \cdot 64$ & 48 \\
\hline & $40-49$ & 16 & & & & & & & 5 & 6 & 1 & 1 & & & 1 & 1 & & & 1 & & & & $6 \cdot 43$ & $1 \cdot 46$ & 31 \\
\hline & $\begin{array}{l}\text { Total } \\
15-49\end{array}$ & 80 & 1 & & & 3 & 4 & 9 & 17 & 15 & 6 & 8 & 6 & 2 & 1 & 3 & 1 & 2 & 1 & 1 & & & & & 39 \\
\hline & $50-59$ & 8 & & & & 1 & & 3 & & 1 & 1 & & 1 & 1 & & & 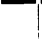 & & & & & & $5 \cdot 79$ & $1 \cdot 44$ & 37 \\
\hline & $60-69$ & 7 & & & & & 1 & & & & 1 & 1 & & & 2 & & 1 & & & & & 1 & $7 \cdot 64$ & $2 \cdot 21$ & 62 \\
\hline & $\begin{array}{l}70 \text { and } \\
\text { Over }\end{array}$ & 4 & & & & & & 1 & 1 & & 1 & 1 & & & & & & & & & & & $5 \cdot 80$ & 0.85 & 50 \\
\hline & $\begin{array}{c}\text { Total } \\
50-70+\end{array}$ & 19 & & & & 1 & 1 & 4 & 1 & 1 & 3 & 2 & 1 & 1 & 2 & & & 1 & & & & 1 & & & 58 \\
\hline
\end{tabular}




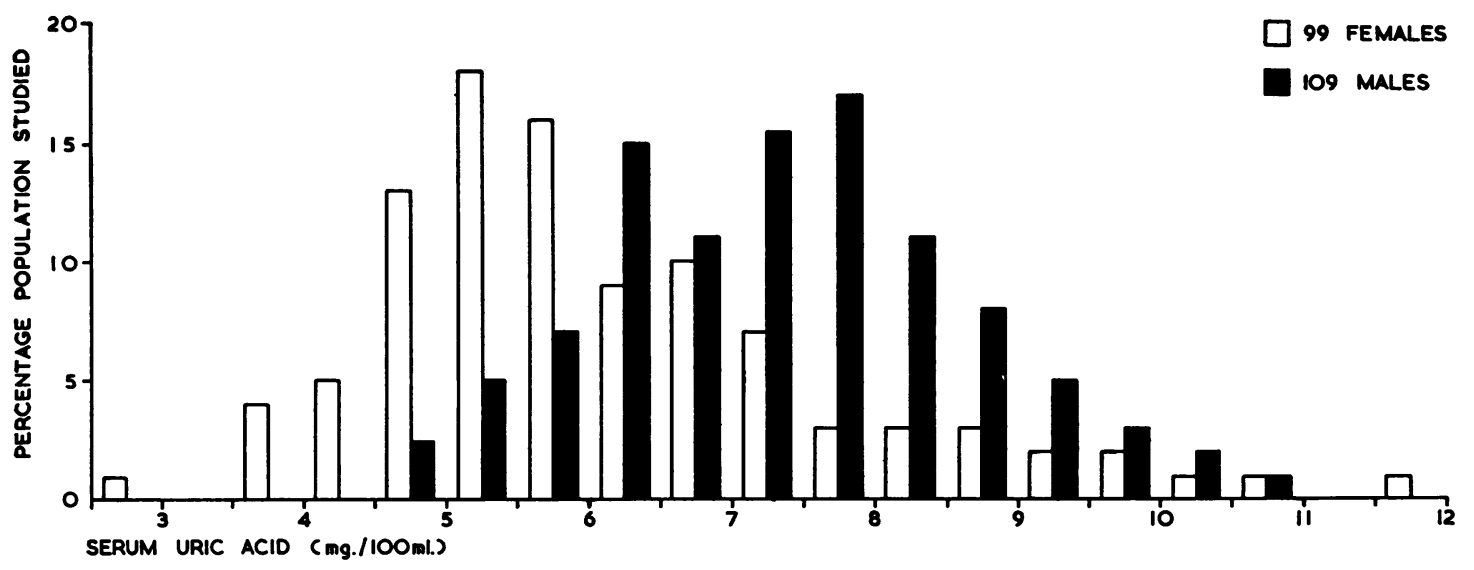

Figure.-Frequency distribution levels of serum uric acid, by sex.

number of females with gout, a prevalence of 2 per cent. ( 2 of 102), was unexpectedly high. One subject was an elderly woman in her sixties (unable to give her exact age) with recurrent severe acute remitting arthritis of the left ankle and serum uric acid level of $11.5 \mathrm{mg} . / 100 \mathrm{ml}$; t the other was a young woman aged 31 with a family history of gout, who was seen in an attack of podagra with a serum uric acid level of $10.0 \mathrm{mg} . / 100 \mathrm{ml}$. and subsequent response to colchicine. The incidence of gout is summarized in Table VII.

\section{Discussion}

These results again confirm the high prevalence of gout and low prevalence of rheumatoid arthritis in the Maori as compared with the European population of New Zealand previously mentioned by Rose and Isdale (1961).
Prior (1962) reported a high prevalence of obesity, diabetes, hypertension, and degenerative cardiovascular disease in the present Maori population sample, together with a high prevalence of gout. $\mathrm{He}$ is finding epidemiological support* for the centuries old (Snapper, 1960), but recently disputed (Joslin, Root, White, and Marble, 1952; Talbott, 1953) clinical concept of a genetically-based diathesis, made manifest by what the French appropriately call sur-alimentation. This epidemiological support for relationships between gout and other diseases accords well with the clinical observations of Kuzell, Schaffarzick, Naugler, Koets, Mankle, Brown, and Champlin (1955) in their series of 520 gouty patients.

The remarkable proportion with hyperuricaemia is notably different from that observed in a group of

* Findings to be published.

TABLE VII

SUMMARY OF FINDINGS IN GOUTY SUBJECTS (INCLUDING ONE PROBABLE CASE-No. 101)

\begin{tabular}{|c|c|c|c|c|c|c|c|c|}
\hline \multirow{2}{*}{ Sex } & \multirow{2}{*}{$\begin{array}{l}\text { Case } \\
\text { No. }\end{array}$} & \multirow{2}{*}{$\begin{array}{c}\text { Age } \\
\text { (yrs) }\end{array}$} & \multicolumn{2}{|c|}{ Podagra } & \multirow{2}{*}{$\begin{array}{c}\text { Other Acute } \\
\text { Remitting } \\
\text { Recurrent Arthritis }\end{array}$} & \multirow{2}{*}{$\begin{array}{c}\text { Serum } \\
\text { Uric Acid } \\
\text { (mg. } / 100 \mathrm{ml} .)\end{array}$} & \multirow{2}{*}{ Diabetes } & \multirow{2}{*}{$\begin{array}{l}\text { Response } \\
\text { to } \\
\text { Colchicine }\end{array}$} \\
\hline & & & History & Observed & & & & \\
\hline \multirow{6}{*}{ Male } & 189 & 32 & + & - & - & $7 \cdot 4$ & - & - \\
\hline & 17 & 49 & + & - & - & $9 \cdot 9$ & - & - \\
\hline & 159 & 49 & + & - & - & $10 \cdot 8$ & + & + \\
\hline & 192 & 54 & + & - & - & $7 \cdot 2$ & - & - \\
\hline & 92 & 58 & + & + & - & $7 \cdot 4$ & - & - \\
\hline & 101 & 59 & + & - & - & 6.9 & + & - \\
\hline \multirow{2}{*}{ Female } & 29 & 31 & - & + & - & $10 \cdot 0$ & - & + \\
\hline & 124 & $60+$ & - & - & + & $11 \cdot 5$ & - & - \\
\hline
\end{tabular}


white Australian blood donors studied by a comparable method (Hendry and others, 1959), and is of considerable interest, not only in connexion with the high prevalence of gout, but also with recent reports of a correlation between hyperuricaemia and cardiac infarction in clinical practice (Kohn and Prozan, 1959; Lovering and Longobardi, 1961). Decker, Lane, and Reynolds (1961) maintain that the incidence of gout rises as the serum uric acid levels of a population increase, and this also finds ample support and could well apply with equal force to other manifestations of the "gouty diathesis"- such as diabetes and degenerative cardiovascular disorders-in certain populations.

Also of interest is the tendency to skewing of the distribution of serum uric acid levels. A similar skewing to the right has been reported in the United Kingdom in women aged 50 and over by Popert and Hewitt (1962), and in Philippinos by Decker and others $(1961,1962)$.

The bimodality of the serum uric acid distribution curve in the men and the skewing to the right in the women suggest the possibility of two sub-groups, one with normal uricaemia and the other with hyperuricaemia. A single gene could be responsible with a large percentage of the population affected, indicating a high degree of polymorphism. The dietary habits and associated obesity could then account for the extreme manifestation of the trait. Other genetic and environmental factors may also be involved in the production of the associated high prevalence of gout itself. The Hawaiian Philippinos studied by Steuermann (1961) were not obese and the evidence of strong genetic influence-particularly in the absence of studies of effects of cocoanut fats on uric acid metabolism-was unequivocal for both gout and hyperuricaemia. The Maori populations studied appear to be under the influence of combined strong genetic and environmental forces.

The prevalence of positive latex-agglutination tests and $x$-ray evidence of degenerative joint disease is of considerable interest when contrasted with the comparative rarity of moderate to severe clinical rheumatoid arthritis in the Maori. Disability from chronic or recurrent gout had been a problem before effective treatment was brought to this group by their general practitioners. Disability from rheumatoid and degenerative joint disease was, however, quite trivial.

The necessary genetic constitution for gout, rheumatoid arthritis, and osteo-arthrosis exists-though possibly with differing emphasis, in both Maori and European populations of New Zealand. Prolonged follow-up studies will show whether the increasing Europeanization of Maori culture will change the prevalence of severe gout and rheumatoid arthritis in opposite ways or not.

\section{Summary}

A rural Maori community has been surveyed for prevalence of rheumatic disorders, with simultaneous assessment of distribution of positive latex-agglutination, serum uric acid levels, and degenerative joint changes in the hands as seen by mass miniature $x$ ray.

The higher prevalence of gout and lower prevalence of rheumatoid arthritis as compared with European New Zealanders, which had been previously reported, was again confirmed; and high prevalence of hyperuricaemia was found.

A recently reported high prevalence of obesity, diabetes, hypertension, and degenerative cardiovascular disease is briefly discussed in relationship to gout and hyperuricaemia.

The serum uric acid level distribution curves show bimodality and favour a frequently occurring genetic cause for the hyperuricaemia and gout. The effect of environmental factors is to be the subject of further study.

This survey was suggested by the Medical Researci Council of New Zealand, the Wellington Medicat Research Foundation, and the Department of Health.

We wish to acknowledge in particular the help of the Tuhoe people of Ruatahuna, Dr. Allan North, and the Director-General of Health, Dr. H. B. Turbott.

\section{REFERENCES}

Abell, L. L. (1960). "Standard Methods of Clinical Chemistry", vol. 2.

Beale, R. N. (1954). Paper read to N.Z. Rheumatism Association.

Decker, J. L., Lane, J. L., and Reynolds, W. E. (1961). Atti X Congr. Int. Reum., vol. 2, p. 671. Minerva Med. (Torino). (1962). Arthr. and Rheum., 5, 144.

Hendry, P. I. A., White, K. H., and Stanger, I. J. (1959). Med. J. Austr., 2, 956.

Joslin, E. P., Root, H. F., White, P., and Marble, A. (1952). "The Treatment of Diabetes Mellitus", 9th ed., p. 93. Lea and Febiger, Philadelphia.

Kellgren, J. H. (1962). Bull. rheum. Dis., 13, 291.

Kohn, P. M., and Prozan, G. B. (1959). J. Amer. med. Ass., 170, 1909.

Kuzell, W. C., Schaffarzick, R. W., Naugler, W. E., Koets, P., Mankle, E. A., Brown, B., and Champlin, B. (1955). J. chron. Dis., 2, 645.

Lennane, G. A. Q., Rose, B. S., and Isdale, I. C. (1960). Ann. rheum. Dis., 19, 120.

Lovering, E. F., and Longobardi, A. (1961). R.I. med.J., 44, 467. 
Popert, A. J., and Hewitt, J. V. (1962). Ann. rheum. Dis., 21, 154.

Prior, I. A. M. (1962). N.Z. med. J., 61, 333.

Rheins, M. S., McCoy, F. W., Burrell, R. G., and Buehler, E. V. (1957). J. Lab. clin. Med., 50, 113.

Rose, B. S. (1956). Paper read to N.Z. Rheumatism Association.

and Isdale, I. C. (1961). Atti X Congr. Int. Reum., vol. 2, p. 1525. Minerva Med. (Torino).

Snapper, I. (1960). "Bedside Medicine", p. 387. Grune and Stratton, New York.

Steuermann, N. (1961). Paper read at C.I.O.M.S. Symposium on "Population Studies in Relation to Chronic Rheumatic Diseases". Rome.

Talbott, J. H. (1953). "Gout and Gouty Arthritis", p. 49. Grune and Stratton, New York.

Une enquête sur le rhumatisme dans une communauté rurale des Maoris en Nouvelle Zélande

\section{RÉSUMÉ}

On procéda à une enquête sur la fréquence des désordres rhumatismaux parmi les Maoris d'une communauté rurale; on détermina en même temps la distribution de la réaction positive de l'agglutination au latex, des taux sériques de l'acide urique et des altérations dégénératives des articulations des mains observées sur des radiophotographies en masse.

On confirma le fait, déja rapporté, que la goutte était plus fréquente et l'arthrite rhumatismale moins fréquente chez les Maoris que chez les habitants d'origine européenne; on trouva aussi une grande fréquence de l'hyperuricémie.
On discute brièvement, par rapport à la goutte et à l'hyperuricémie, l'obésité, le diabète, l'hypertension et la maladie cardiovasculaire dégénérative dont la grande fréquence fut récemment rapportée.

Les courbes de distribution des taux de l'acide urique dans le sérum tendent à la bimodalité et montrent de la partialité à l'origine génétique, souvent observée, de l'hyperuricémie et de la goutte. L'effet des facteurs ambiants formera le sujet d'un autre travail.

Investigación del reumatismo en una comunidad rural de Maoríes en Nueva Zelandia

\section{SUMARIO}

Se investigó la frecuencia de los disturbios reumatoides entre los Maoríes de una comunidad rural y se determinó al mismo tiempo la distribución de la reacción positiva de aglutinación al latex, de los niveles séricos del ácido úrico y de las alteraciones degenerativas de las articulaciones de manos observadas en radiofotografías en miniatura.

Se confirmó el hecho, ya relatado, de que la gota fué más frecuente y la artritis reumatoide menos frecuente entre los Maoríes que entre los europeos en Nueva Zelandia; se halló también una gran frecuencia de hiperuricemia.

Se discuten brevemente, en relación con la gota y la hiperuricemia, la obesidad, la diabetes, la hipertensión y la enfermedad cardiovascular degenerativa, cuya frecuencia elevada fué recientemente relatada.

Las curvas de distribución de las cifras del ácido úrico en el suero tienden a ser bimodales y favorecen la causa genética, a menudo observada, de la hiperuricemia y de la gota. El efecto de factores ambientes formara el sujeto de un otro trabajo. 